\title{
ABSTRACTS
}

\section{Solidarity and social democracy}

\author{
By Rodolfo Arango, Bogotá
}

Social solidarity is a central but neglected term in democratic and rule of law based constitutional theory. Nevertheless it can be revived as the third element of the revolutionary inheritance of the 18th century. This paper shall help to analyze the empirical and normative understanding of solidarity. With that a new understanding of universal solidarity in times of global dependence can be defended: Solidarity as responsibility to combat structural injustices. This concept, inspired by Iris Marion Young's work, can play an important role as the basis of social democracy, as the recognition of social basic rights by the Columbian constitutional jurisdiction shows.

\section{Rule of Law, Good Governance and Development}

By Wolfgang Muno, Erfurt

Rule of law, or "Rechtsstaatlichkeit", is en vogue in political science. Rule of law is seen as a solution for many problems like settling civil wars, democracy, development or poverty. An important role played the World Bank and the discourse about Good Governance, which implies Rule of law, as well as the World Bank's Worldwide Governance Indicators (WGI), a meta-index for measuring good governance and rule of law. Many empirical studies using WGI-data claim a strong correlation between rule of law and development. The data are used for decision-making in development policy, too. However, WGI and measuring rule of law bear problems, especially reducing rule of law to property rights. It hardly makes sense to treat rule of law as an isolated factor, therefore simple answers to complicated development questions should not be expected.

\section{Government Intervention in the Chinese Real Estate Market - Issues of Legality and Legal Remedies}

By Björn Ahl, Cologne

As an economically successful authoritarian state, China appears to be an alternative to liberal rule-of-law systems. Theories on the relationship of law and economic development normally require a sound legal framework, rule based administration and strong legal institutions as a 
precondition of economic growth. China seems to contradict such general hypotheses on law and development. The article examines the legality of measures that were adopted by the Beijing Municipal Government to curb the rise of housing prices and prevent a property bubble. The normative documents providing for housing purchase restrictions are found to violate procedural and substantive standards. Chinese law provides for legal remedies that permit courts to review the legality of the purchase restrictions, if they form the legal basis of an administrative act. However, courts appear reluctant to challenge the government's measures against rising housing prices. Finally, the implementation of measures that contradict the legal system is explained on the basis of 'socialist rule of law', different modes of the party state's operation as well as a 'turn against law'.

\section{The place of Muslim law in Cameroon's legal system}

By Joseph Nzalie Ebi, Dschang

Cameroon has a mixed judicial system in which the received English and French laws coexist with numerous systems of customary law including Muslim law. For having been preceded by a numerically superior customary law and followed by two strong colonial laws, Muslim law finds itself in a less vantage position. It is assimilated to customary law and thus subjected to the rules of exclusion applicable to that system of law. Whether this in any way diminishes its value as a system of law is the main objective of this article. After examining the sources and elucidating the different appellation by which the law derived from Islam is known, the response to the main question will be sought by highlighting a number of points: The status of the law in the midst of plenty, the rules of its application, and above all, the attitude of the courts in case of conflict with the other laws. 